\title{
Prospects of extruded grain legumes for meat-type chickens: Effect on endogenous enzyme activity, starch utilization, growth and organ development \\ ${ }^{1 *}$ Adeleye, O. O., ${ }^{2}$ Oduntan, O. B., ${ }^{1}$ Agunbiade, O. and ${ }^{1}$ Farayibi, D. \\ ${ }^{\prime}$ Agricultural Biochemistry and Nutrition, Department of Animal Science, University of Ibadan, Nigeria \\ ${ }^{2}$ Department of Aquaculture and Fisheries Management, \\ University of Ibadan, Nigeria
}

Abstract

*Corresponding author: ooadeleye@rocketmail.com; +2348037074723

Extrusion cooking, a high-temperature short-time processing technique holds promise for lowering enzyme inhibitor activities and improving nutrient bioavailability in grain legumes, thus improving their feeding value. The effect of extrusion cooking of two grain legumes; pigeon pea (Cajanus cajan) and bambara groundnut (Vigna subterranean) at varied temperatures on growth performance, endogenous enzyme activity and organ development of 35d-old meat-type chickens was investigated. Pigeon pea and bambara groundnut were milled and extruded at two temperatures $\left(100^{\circ} \mathrm{C}\right.$ and $\left.140^{\circ} \mathrm{C}\right)$ from which six diets were formulated containing $30 \mathrm{~g} / 100 \mathrm{~g}$ diet of non-extruded (control), $100^{\circ} \mathrm{Cor} 140^{\circ} \mathrm{C}$ extrudates of bambara groundnut or pigeon pea. Two hundred and fifty-two, one day-old, meat-type chicks were allotted to the six diets in six replicates, seven birds each. Weight gain and feed intake (FI)were monitored weekly and feed conversion ratio (FCR) was estimated. Relative weight (g) of pancreas, proventriculus, gizzard and liver as well as duodenal, jejunal and ileal lengths and weights were measured. Activities of pancreatic amylase, proteases; chymotrypsin and trypsin, and brush border disaccharidases; sucrase and maltase were also assayed in the pancreas, ileal and jejunal digesta, and ileal and jejunal tissues respectively. Data was analyzed using ANOVA $(p<0.05)$ and pre-planned contrasts, elucidating the effect of extrusion (raw vs extruded; $100^{\circ} \mathrm{C}$ and $140^{\circ} \mathrm{C}$ ) and temperatures $\left(100^{\circ} \mathrm{Cvs} 140^{\circ} \mathrm{C}\right.$ ) on each grain legume investigated. Weight gain of chickens on both bambara groundnut and pigeon pea diets were not affected by extrusion temperatures or extrusion throughout the study period except during 8-14d in the pigeon pea groups. However, FI significantly reduced and $F C R$ improved with extrusion cooking and extrusion temperatures $(P<0.05)$ for meat-type chickens on the pigeon pea diets. The FI also reduced and FCR improved with extrusion cooking and extrusion temperatures for meat-type chickens on the bambara groundnut diets between 8-21d and 29-35d of age (FI: $604.83 \pm 0.71 \mathrm{~g} v \mathrm{~s} 530.58 \pm 6.47 \mathrm{~g}$ and $532.20 \pm 15.36 \mathrm{~g}$ respectively; FCR: $3.89 \pm 0.15$ vs $3.25 \pm 0.17$ and $3.27 \pm 0.21$, respectively). Relative organ weights, weights and lengths of intestinal segments as well as pancreatic amylase and protease activities were not influenced by extrusion cooking or extrusion temperatures.

Keywords: high-temperature short-time extrusion cooking; grain legumes; alternative energy-protein ingredients; broiler chicken

Prospection de légumineuses à grains extrudées pour les poulets de type viande : effet sur la croissance, le développement des organes, l'activité enzymatique endogène et l'utilisation de l'amidon chez les poulets de type viande

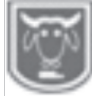$$
\text { (t) }
$$

Résumé

La cuisson par extrusion, une technique de traitement de courte durée à haute température, est prometteuse pour réduire les activités des inhibiteurs enzymatiques et améliorer la 
biodisponibilité des nutriments dans les légumineuses à grains, améliorant ainsi leur valeur nutritive. L'effet de la cuisson par extrusion de deux légumineuses à grains; Cajanus cajan (pois cajan) et Vigna subterranean (arachide bambara) à des températures variées sur les performances de croissance, l'activité enzymatique endogène et le développement des organes de poulets de type viande âgés de 35 jours ont été étudiés. Le pois cajan et le pois cajan ont été broyés et extrudés à deux températures $(1000 \mathrm{C}$ et $140 \mathrm{oC})$ à partir desquels six régimes ont été formulés contenant $30 \mathrm{~g} / 100 \mathrm{~g}$ de régime alimentaire non extrudé (témoin), $100 \circ$ C ou $140 o C$ d'extrudés de pois cajan ou de pois cajan. Deux cent cinquante-deux poussins de type viande d'un jour ont été répartis dans les six régimes en six répétitions, sept oiseaux chacun. Le gain de poids et la prise alimentaire (PA) ont été surveillés chaque semaine et le ratio de conversion alimentaire (RCA) a été estimé. Le poids relatif du pancréas, du proventricule, du gésier et du foie (g) ainsi que les longueurs et poids duodénaux, jéjunaux et iléaux ont été mesurés. Activités de l'amylase pancréatique, des protéases ; la chymotrypsine et la trypsine, et les disaccharidases de bordure en brosse; la sucrase et la maltase ont également été dosées dans le pancréas, le digesta iléal et jéjunal et les tissus iléaux et jéjunaux respectivement. Les données ont été analysées à l'aide d'ANOVA $(p<0,05)$ et de contrastes pré-planifiés, pour élucider l'effet de l'extrusion (brut vs extrudé ; $100 \mathrm{oC}$ et $140 \mathrm{oC}$ ) et des températures (100 oC contre 140oC) sur chaque légumineuse à grains étudiée. Le gain de poids des poulets recevant à la fois des régimes à base d'arachide et de pois cajan n'a pas été affecté par les températures d'extrusion ou l'extrusion tout au long de la période d'étude, sauf pendant 8 à 14 jours dans les groupes de pois cajan. Cependant, le $P A$ a diminué de manière significative $(P<0,05)$ et le $R C A$ s'est amélioré avec la cuisson par extrusion et les températures d'extrusion pour les poulets de type viande sur les régimes de pois cajan. Le PA a également diminué et le RCA s'est amélioré avec la cuisson par extrusion et les températures d'extrusion pour les poulets de type viande sur les régimes à base

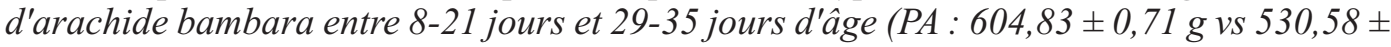

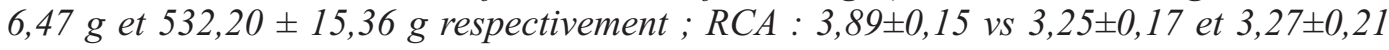
respectivement). Les poids relatifs des organes, les poids et les longueurs des segments intestinaux ainsi que les activités de l'amylase et de la protéase pancréatiques n'étaient pas influencés par la cuisson par extrusion ou les températures d'extrusion.

Mots-clés : Cuisson par extrusion de courte durée à haute température ; légumineuses à grains; ingrédients protéinés énergétiques alternatifs; poulet à griller

\section{Introduction}

The high cost of conventional energy and protein ingredients used in poultry feeding has continued to negatively impact the growth of the poultry industry in Nigeria. Fluctuations in the supply and cost of maize and soyabean meal (Figure 1) are attributed to increased competition for maize and soyabean by the food, feed and biofuel industries, climate change induced weather change, occurrence of new crop pests and diseases, scarcity of resources (such as fertile land, water for irrigation and fertilizers), and, political and socioeconomic constraints. Lesser known grain legumes such as kidney beans (Phaseolus vulgaris L.), field bean (Vicia faba L.), African yam bean (Sphenostylis stenocarpa), pea (Pisum sativum L.), lupin (Lupinus albus L.) and chickpea (Cicer arientum L.), have been considered as alternative protein-energy ingredients for poultry (Arija et al., 2006; Jozefiak et al., 2006; Brenes et al., 2008; Nalle et al., 2011; Son and Ravindran, 2012; Raji et al., 2016; Abdulla et al., 2017) due to their superior protein value in comparison to maize, as well as similarity in gross energy when compared to maize and soyabean meal (Heuze et al., 2016). However, the 


\section{Adeleye, Oduntan, Agunbiade and Farayibi}

partial resistance of legume starches to amylase digestion (Velasco et al., 1997) and the presence of antinutritive bioactives (such as protease inhibitors, lectins, tannins, phytate and haemagglutinins) in grain legumes (FAO, 1995; Capos-Vegas et al., 2016) stall their use as feed ingredients for poultry. However, heat treatment of grain legumes by traditional and industrial methods are reported to irreversibly deactivates heat-labile antinutritive bioactives improving nutrient digestibility and bioavailability to varying degrees.(Alonso etal., 1998, 2000a)

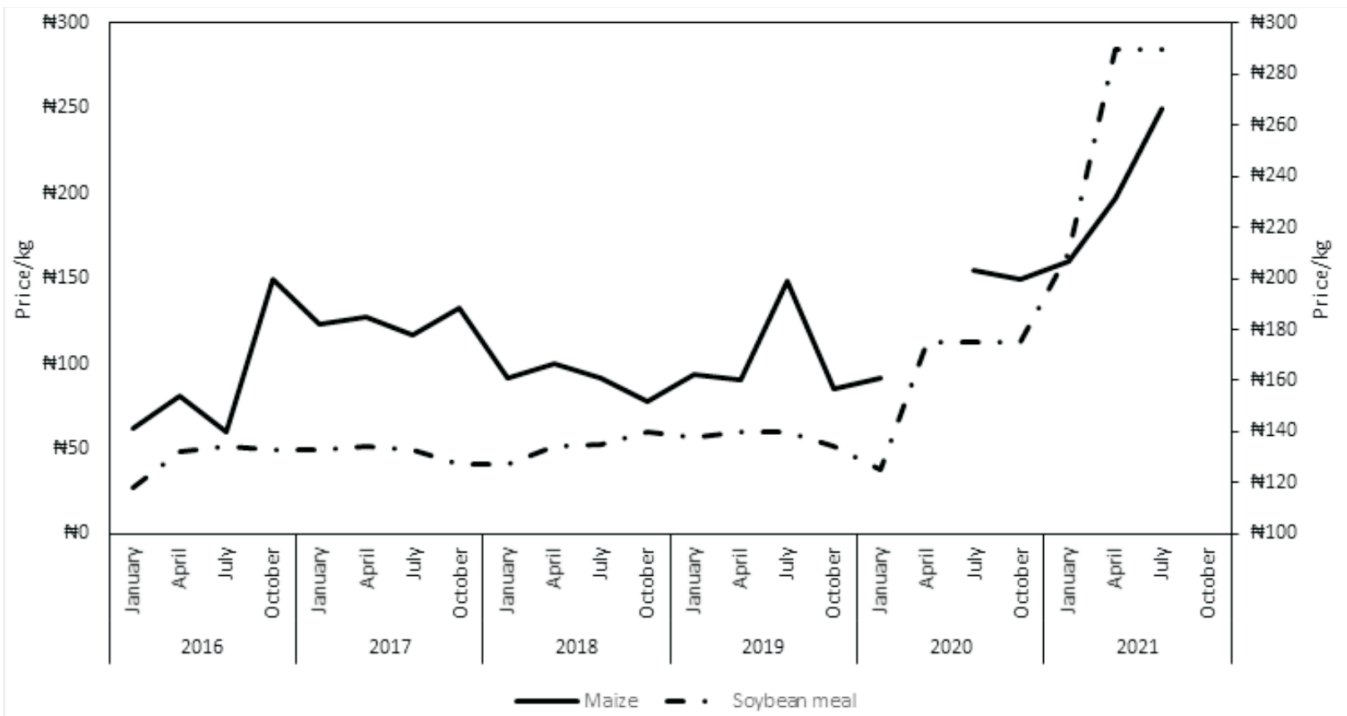

Figure 1. Trend of soyabean meal and maize prices 2016 -2021 (Personal communications)

High-temperature short-time (HTST) extrusion cooking, which is an industrial technique that subjects moist food/feed ingredients to a combination of high temperature, pressure and mechanical shear over a short time period, has been widely adopted in the food and feed industry due to its practicality, high productivity, efficiency, and nutrient retention. The ability of HTST cooking to influence nutrient bioavailability is pronounced in the protein and starch components of ingredients. Nutritional implications for HTST extrusion cooking of grain legumes has been investigated in vitro and in vivo and attributed to modified physicochemical properties of extrudates, thermal degradation of sugars and amino acids, and gelatinization of starch during the HTST extrusion cooking process. Other implications for HTST extrusion cooking of grain legumes include significant lowering of feed rancidity and microbial contamination. Conversely, severe extrusion conditions have been implicated in impaired nutrient bioavailability owing to formation of late Maillard reaction products such as melanoides. Maillard's reaction is an integral part of feed processing arising from the binding of the amino group of reactive amino acids such as lysine, and the carbonyl group of reducing sugars such as glucose and lactose.(Singh et al 2007; Mavromichallis, 2015). Earlier reports of in vitro protein digestibility of Sphenostylis stenocarpa (African yam bean), Cajanus cajan (pigeon pea) and Vigna subterranean (bambara groundnut)showed a 22.16-30.8\% improvement in protein digestibility when $100^{\circ} \mathrm{C}$ and $140^{\circ} \mathrm{C}$ extrudates of Sphenostylis stenocarpa and Cajanus cajan were 
assessed without any effect of extrusion temperature observed in extrudates of Vigna subterranean, while in vitro starch digestibility was improved in $140^{\circ} \mathrm{C}$ extrudates of Cajanus cajan and Vigna subterranean compared to $100^{\circ} \mathrm{C}$ extrudates, with no effect of varied extrusion temperatures in Sphenostylis stenocarpa. Hence this study seeks to validate these findings in vivo by investigating the effect of varied extrusion temperatures on the growth performance, organ development, endogenous enzyme activity and starch utilization in meat-type chickens fed Cajanus cajan (pigeon pea) and Vigna subterranean (bambara groundnut)-based diets.

\section{Materials and methods}

Test product, extrusion and diets

Cajanus cajan and Vigna subterranean were purchased from a grain market in Ibadan, cleaned of debris and finely ground through a $0.5 \mathrm{~mm}$ screen in the hammer mill. Thereafter, the milled grains were conditioned to $20 \%$ moisture and fed manually through a feeding unit at $33.6 \mathrm{~kg} / \mathrm{h}$ into a single-screw extruder of compression ratio, 3:1; screw length-to-diameter (L/D) ratio, $6: 1$ and barrel length, $317.50 \mathrm{~mm}$. The extruder operated at screw speed of $305 \mathrm{rpm}$ through an $8 \mathrm{~mm}$ die hole at varied extrusion temperatures of $100^{\circ} \mathrm{C}$ or $140^{\circ} \mathrm{C}$. The unextruded and extruded grain legumes were assayed for nutritional composition (Table 1) and subsequently incorporated at $30 \%$ of a starter-grower broiler diet (Table 2) formulated to provide required nutrients to support growth and performance.(NRC, 1994).

Table 1 : Determined composition of unextruded and extruded bambara groundnut (Vigna subterranean) and pigeon pea (Cajanus cajan) ${ }^{\dagger}$

\begin{tabular}{|c|c|c|c|c|c|c|c|}
\hline & & $\begin{array}{l}\text { Crude } \\
\text { protein } \\
(\%)\end{array}$ & $\begin{array}{l}\text { Crude } \\
\text { fibre }(\%)\end{array}$ & $\begin{array}{l}\text { Ether } \\
\text { extract } \\
(\%)\end{array}$ & $\begin{array}{l}\text { Nitrogen- } \\
\text { free } \\
\text { extract } \% \text { ) }\end{array}$ & Ash (\%) & $\begin{array}{l}\mathrm{AMEn}^{+} \\
(\mathrm{kcal} / \mathrm{kg})\end{array}$ \\
\hline \multirow{3}{*}{$\begin{array}{l}\text { Bambara } \\
\text { groundnut } \\
\text { (Vigna } \\
\text { subterrenean) }\end{array}$} & BBR & $\begin{array}{l}20.50 \pm \\
0.01\end{array}$ & $\begin{array}{l}4.03 \pm \\
0.05\end{array}$ & $\begin{array}{l}11.45 \pm \\
1.28\end{array}$ & $\begin{array}{l}51.42 \pm \\
1.27\end{array}$ & $\begin{array}{l}2.90 \pm \\
0.00\end{array}$ & 2838.66 \\
\hline & BB100 & $\begin{array}{l}20.27 \pm \\
0.01\end{array}$ & $\begin{array}{l}6.13 \pm \\
0.46\end{array}$ & $\begin{array}{l}5.15 \pm \\
0.65\end{array}$ & $\begin{array}{l}55.87 \pm \\
0.87\end{array}$ & $\begin{array}{l}3.63 \pm \\
0.08\end{array}$ & 2492.14 \\
\hline & BB140 & $\begin{array}{l}19.91 \pm \\
0.01\end{array}$ & $\begin{array}{l}6.03 \\
0.06\end{array}$ & $\begin{array}{l}0.77 \pm \\
0.18\end{array}$ & $\begin{array}{l}60.36 \pm \\
0.16\end{array}$ & $\begin{array}{l}3.63 \pm \\
0.03\end{array}$ & 2494.65 \\
\hline \multirow{3}{*}{$\begin{array}{l}\text { Pigeon pea } \\
\text { (Cajanus } \\
\text { cajan) }\end{array}$} & PPR & $\begin{array}{l}21.20 \pm \\
0.02\end{array}$ & $\begin{array}{l}7.72 \pm \\
0.25\end{array}$ & $\begin{array}{l}8.50 \pm \\
3.10\end{array}$ & $\begin{array}{l}48.59 \pm \\
2.74\end{array}$ & $\begin{array}{l}4.88 \pm \\
0.03\end{array}$ & 2172.62 \\
\hline & PP100 & $\begin{array}{l}20.07 \pm \\
0.00\end{array}$ & $\begin{array}{l}8.02 \pm \\
0.02\end{array}$ & $\begin{array}{l}3.37 \pm \\
0.16\end{array}$ & $\begin{array}{l}55.58 \pm \\
0.61\end{array}$ & $\begin{array}{l}4.50 \pm \\
0.20\end{array}$ & 2164.31 \\
\hline & PP140 & $\begin{array}{l}18.66 \pm \\
0.01\end{array}$ & $\begin{array}{l}9.35 \pm \\
0.13\end{array}$ & $\begin{array}{l}2.03 \pm \\
0.81\end{array}$ & $\begin{array}{l}55.60 \pm \\
0.69\end{array}$ & $\begin{array}{l}5.02 \pm \\
0.12\end{array}$ & 1888.19 \\
\hline
\end{tabular}

Values are presented as means of triplicate determinations \pm standard deviation BBR - unextruded bambara groundnut (Vigna subterranean); BB100 - Bambara groundnut (Vigna subterranean) extruded at $100^{\circ} \mathrm{C}$; BB140 - bambara groundnut (Vigna subterranean) extruded at $140^{\circ} \mathrm{C}$; PPR - unextruded pigeon pea (Cajanus cajan); PP100 - pigeon pea (Cajanus cajan) extruded at $100^{\circ} \mathrm{C}$; PP140 - pigeon pea (Cajanus cajan) extruded at $140^{\circ} \mathrm{C}$ ${ }^{\ddagger}$ Calculated value; European Table of Energy Values for Poultry Feedstuff (WPSA, 1986)

${ }^{\dagger}$ Adeleye et al. (2020) 
Table 2 : Ingredients and calculated nutrient composition of experimental diets (g/kg as fed) containing unextruded and extruded bambara groundnut and pigeon pea

\begin{tabular}{|c|c|c|c|c|c|c|}
\hline \multirow[t]{2}{*}{ Ingredients } & \multicolumn{3}{|c|}{ bambara groundnut } & \multicolumn{3}{|c|}{ pigeon pea } \\
\hline & BBR & BB100 & BB140 & PPR & PP100 & PP140 \\
\hline Maize & 320 & 320 & 320 & 340 & 340 & 340 \\
\hline Soyabean meal $(44 \% \mathrm{CP})$ & 275 & 275 & 275 & 255 & 255 & 255 \\
\hline Bambara groundnut - unextruded & 300 & - & - & - & - & - \\
\hline $100^{\circ} \mathrm{C}$ bambara groundnut extrudate & - & 300 & - & - & - & - \\
\hline $140^{\circ} \mathrm{C}$ bambara groundnut extrudate & - & - & 300 & - & - & - \\
\hline Pigeon pea - unextruded & - & - & - & 300 & - & - \\
\hline $100^{\circ} \mathrm{C}$ pigeon pea extrudate & - & - & - & - & 300 & - \\
\hline $140^{\circ} \mathrm{C}$ pigeon pea extrudate & - & - & - & - & - & 300 \\
\hline Fish meal $(72 \% \mathrm{CP})$ & 30 & 30 & 30 & 30 & 30 & 30 \\
\hline Soy oil & 42 & 42 & 42 & 42 & 42 & 42 \\
\hline Limestone & 10 & 10 & 10 & 10 & 10 & 10 \\
\hline Dicalcium phosphate & 15 & 15 & 15 & 15 & 15 & 15 \\
\hline Vitamin-mineral premix & 2.5 & 2.5 & 2.5 & 2.5 & 2.5 & 2.5 \\
\hline Lysine- $\mathrm{HCl}$ & 1 & 1 & 1 & 1 & 1 & 1 \\
\hline DL methionine & 2 & 2 & 2 & 2 & 2 & 2 \\
\hline Sodium chloride & 2.5 & 2.5 & 2.5 & 2.5 & 2.5 & 2.5 \\
\hline \multicolumn{7}{|l|}{ Calculated nutrients } \\
\hline Metabolizable energy (ME, kcal/kg) & 3054 & 2950 & 2950 & 2874 & 2872 & 2790 \\
\hline Crude protein, $\%$ & 23.3 & 23.2 & 23.1 & 22.8 & 22.4 & 22.0 \\
\hline Crude fibre, $\%$ & 3.9 & 4.5 & 4.5 & 4.9 & 5.0 & 5.4 \\
\hline Calcium, \% & 1.1 & 1.1 & 1.1 & 1.1 & 1.1 & 1.1 \\
\hline Methionine, $\%$ & 0.6 & 0.6 & 0.6 & 0.6 & 0.6 & 0.6 \\
\hline Lysine, $\%$ & 1.4 & 1.4 & 1.4 & 1.5 & 1.5 & 1.5 \\
\hline Phosphorus, \% & 0.6 & 0.6 & 0.6 & 0.7 & 0.7 & 0.7 \\
\hline
\end{tabular}

${ }^{1}$ Optimix poultry chick nourisher, Animal Care, Nigeria. Provided the following per $\mathrm{kg} /$ diet: vitamin $\mathrm{A}$, 20,000 IU; vitamin D3, 4,000 IU; vitamin E, 20 mg; vitamin K3, 4 mg, vitamin B1, 3 mg; vitamin B2, $10 \mathrm{mg}$; niacin $16 \mathrm{mg}$; calpan $16 \mathrm{mg}$; vitamin B6, $6 \mathrm{mg}$; vitamin B12, $0.03 \mathrm{mg}$; choline chloride, 200 $\mathrm{mg}$; folic acid, $2 \mathrm{mg}$; biotin, $0.1 \mathrm{mg}$; manganese, $120 \mathrm{mg}$; iron, $40 \mathrm{mg}$; zinc, $100 \mathrm{mg}$, copper, $10 \mathrm{mg}$; iodine, $2 \mathrm{mg}$; cobalt, $0.4 \mathrm{mg}$; selenium, $0.4 \mathrm{mg}$; antioxidant, $250 \mathrm{mg}$ ${ }^{2}$ Calculated analysis based on nutritional values of feed ingredients (NRC, 1994; Feedipedia) ${ }^{3} \mathrm{BBR}$ - unextruded bambara groundnut (Vigna subterranean); BB100 - bambara groundnut (Vigna subterranean) extruded at $100^{\circ} \mathrm{C}$; BB140 - bambara groundnut (Vigna subterranean) extruded at $140^{\circ} \mathrm{C}$; PPR - unextruded pigeon pea (Cajanus cajan); PP100 - pigeon pea (Cajanus cajan) extruded at $100^{\circ} \mathrm{C}$; PP140 - pigeon pea (Cajanus cajan) extruded at $140^{\circ} \mathrm{C}$

\section{Experimental site, housing and animals}

This study was conducted at the Poultry Unit, Teaching and Research Farm, University of Ibadan, Ibadan, Nigeria and lasted for 35 days. A total of 252 day-old chicks were purchased from a reputable hatchery in Ibadan metropolis. Chicks were weighed on arrival and transferred to a deep litter house and brooded on wood shavings for seven days.

Temperature was maintained at $32^{\circ} \mathrm{C}$ and a 24L:0D, lighting programme was observed during the brooding period, and thereafter ambient temperature of $24-29^{\circ} \mathrm{C}$ and natural illumination (14L:10D) was observed for the rest of the study. At the end of the 


\section{Prospecting extruded grain legumes for meat-type chickens}

brooding period, the chicks were weighed and randomly allocated to one of 36 groups (7 chicks per group) based on weight equalization using the Experimental Animal Allotment Program (Kim and Lindemann, 2007). Each group was housed in a unit with dimensions; $148 \mathrm{~cm} \times 96 \mathrm{~cm}$ $\times 116 \mathrm{~cm}$ within a battery cage system and randomly allotted to one of the experimental diets in six replicates. Diets were provided in mash form with titanium dioxide added at $0.5 \%$ of the complete diet as an indigestible marker. Diets and water were offered ad libitum.

\section{Sampling and data collection}

Each chick was weighed on day 14, 21, 28 and 35 of the study. Feed consumption was measured per unit at the same time and feed conversion ratio was calculated weekly. At 21d of age, two birds per replicate were euthanized by exsanguination, the pancreas, jejunum and ileum were biopsied and digesta harvested from the distal jejunum and ileum. Biopsies were homogenized in saline water on ice for about 5 minutes and subsequently centrifuged at $4000 \times g$ for 10 minutes to remove larger cell debris with only small losses of enzyme activity. The supernatant was transferred to a $2 \mathrm{~mL}$ tube and stored at $20^{\circ} \mathrm{C}$ for estimation of the activity of amylase and disaccharidases; sucrase and maltase. Digesta was centrifuged at 12000 $\times g$ for 5 minutes and the supernatant transferred to a $2 \mathrm{~mL}$ tube and stored at $20^{\circ} \mathrm{C}$ for estimation of the activity of serine proteases; trypsin and chymotrypsin. From day 32-34 of the study, samples of excreta were collected daily and subsequently pooled on replicate basis. At $35 \mathrm{~d}$ of age, another two chickens were randomly selected per replicate and euthanized by exsanguination. Small intestinal sections; duodenum, jejunum and ileum were harvested, measured using a tape measure and then weighed, and the relative length $(\mathrm{cm} / 100 \mathrm{~g} \mathrm{BW})$ and weight $(\mathrm{g} / 100 \mathrm{~g}$ BW) were estimated. The pancreas, liver, proventriculus and gizzard were also harvested, cleaned of adhering tissues, weighed, and relative organ weights were computed. Digesta was also collected from the distal jejunum and ileum, and approximately $5 \mathrm{~cm}$ of the jejunum and ileum was collected, flushed with distilled water and fixed in $10 \%$ formalin for 48 hours. Thereafter, the jejunal and ileal sections were dehydrated, embedded in paraffin, sliced into $5 \mu \mathrm{m}$ thick sections and fixed on slides. Samples of digesta and excreta were dried in a forced air oven at $55^{\circ} \mathrm{C}$ prior to chemical analyses.

\section{Chemical analyses}

Amylase activity was estimated by the reaction of crude enzyme extracts of the pancreas with QCA amylase liquid which contains the chromogenic substrate 5ethylidene- $G_{7} \rho$-nitrophenol bound to a maltose oligosaccharide (Química Clínica Aplicada S.A), and disaccharidase; sucrase and maltase activity estimated by the method of Dahiqvist (1984) based on the reaction between crude enzyme extracts of the jejunal and ileal tissues, disaccharide standards solutions and a glucose/peroxidase reagent (Química Clínica Aplicada S.A). Activity of the serine proteases; trypsin and chymotrypsin in crude extracts of the digesta were determined by their reaction with the chromogenic substrates N-benzoyl-DLarginine-4-nitroanilide hydrochloride (BAPNA, B-4875, Sigma-Aldrich) and Nbenzoyl-L-tyrosine- $\rho$-nitroanilide (BTPNA, B-6760, Sigma-Aldrich), respectively. Jejunal and ileal digesta, and excreta samples were assayed for moisture (AOAC, 1995) and total starch (Vasantan, 2001), and residual starch was calculated. The jejunal and ileal tissue slides were stained with haematoxylin and eosin and subsequently examined under a digital light microscope (VJ-2005-DN Model; BioMicroscope) fitted with mitotic images plus 2.0 digital microscopy software and measurements of the villus height, crypt 


\section{Adeleye, Oduntan, Agunbiade and Farayibi}

depth and thickness of the muscularis were done using the TS VIEW CX Image software (File version 6.2.4.3).

\section{Statistical analysis}

Data obtained were subjected to a one-way analysis of variance and pre-planned contrasts elucidating the effect of extrusion (raw vs extruded; $100^{\circ} \mathrm{C}$ and $140^{\circ} \mathrm{C}$ ) and temperatures $\left(100^{\circ} \mathrm{C}\right.$ vs $\left.140^{\circ} \mathrm{C}\right)$ on each grain legume investigated. The JASP statistical software (version 0.14.1) (JASP, 2020) was used, and

significance was based on a $5 \%$ probability level.

\section{Results and discussion}

Bambara groundnut and pigeon pea are sources of energy and crude protein $(\sim 37$ $45 \%$ starch and 18-28\% crude protein) (Oshodi et al., 1993; Adeleye et al., 2020b). However, like other grain legumes, their use in poultry diets is impaired by their inherent antinutritional factors resulting in poor utilization of these grains by consuming animals (Singh et al., 2007). In vitro evaluations have established that the heat treatment associated with extrusion cooking has the ability to achieve deactivation of these inherent antinutrients as well as improve the digestibility of their starch and protein (Adeleye et al., 2020a,b). The determined composition and estimated apparent metabolizable energy corrected for nitrogen (AMEn)of extruded and unextruded bambara groundnut (Vigna subterranean) and pigeon pea (Cajanus cajan) are shown in Table 1, and a detailed discourse of the effect of extrusion cooking and extrusion temperatures on their nutritional profile is provided in an earlier publication (Adeleye et al., 2020b). Earlier research support the feeding of heat treated bambara groundnut and pigeon pea up to 30 and $27 \%$ respectively in the diets of meattype chickens without detrimental effects (Ani and Okeke, 2011; Bello et al., 2005), informing the inclusion of 100 and $140^{\circ} \mathrm{C}$ extrudates of bambara groundnut and pigeon pea at $30 \%$ of the diet in the current study. The performance of meat-type chickens fed the experimental diets from 8$35 \mathrm{~d}$ is summarized in Table 3 . There was no significant effect of extrusion cooking of bambara groundnut at different extrusion cooking temperatures (PP100 vs PP140) on body weight gain (BWG) and feed conversion ratio (FCR), however, extrusion cooking (unextruded $v s$ extruded) significantly reduced body weight gain $(\mathrm{p}=$ 0.05 ) of meat-type chickens on 15-21d. A reduction in feed intake as a result of extrusion cooking (unextruded $v s$ extruded) was also observed at 8-14d, 15-21d and 29$35 \mathrm{~d}$, while FCR was improved during the same period. Feed intake declined significantly and FCR improved with extrusion cooking of pigeon pea (unextruded $v s$ extruded) at higher temperature (PP100 vs PP140) throughout the study, while extrusion cooking of pigeon pea (unextruded vs extruded) at different temperatures (PP100 vs PP140) significantly improved BWG at 15-21d. Extrusion of grain legumes seems to have different effects on growth performance of meat-type chickens and may be attributed to differences in extrusion characteristics, extruder properties, physicochemical properties of different grain legumes in digesta (Hejdysz et al., 2018) or null effect of the extrusion process on heat stable antinutritional bioactives such as phytate (Rutkowski et al., 2016). For example, similar to our observations in the current study feeding of extruded faba beans at $300 \mathrm{~g} / \mathrm{kg}$ diet depressed feed intake and improved FCR without any significant effect on body weight gain (Hejdysz et al., 2019). However, extrusion cooking of narrow-leafed lupin seeds did not influence feed intake, body weight gain, or FCR of meat-type chickens at 0-14d and 15-35d (Hejdysz et al., 2018), while extrusion of peas did not influence feed intake, BWG, or FCR of meat-type 


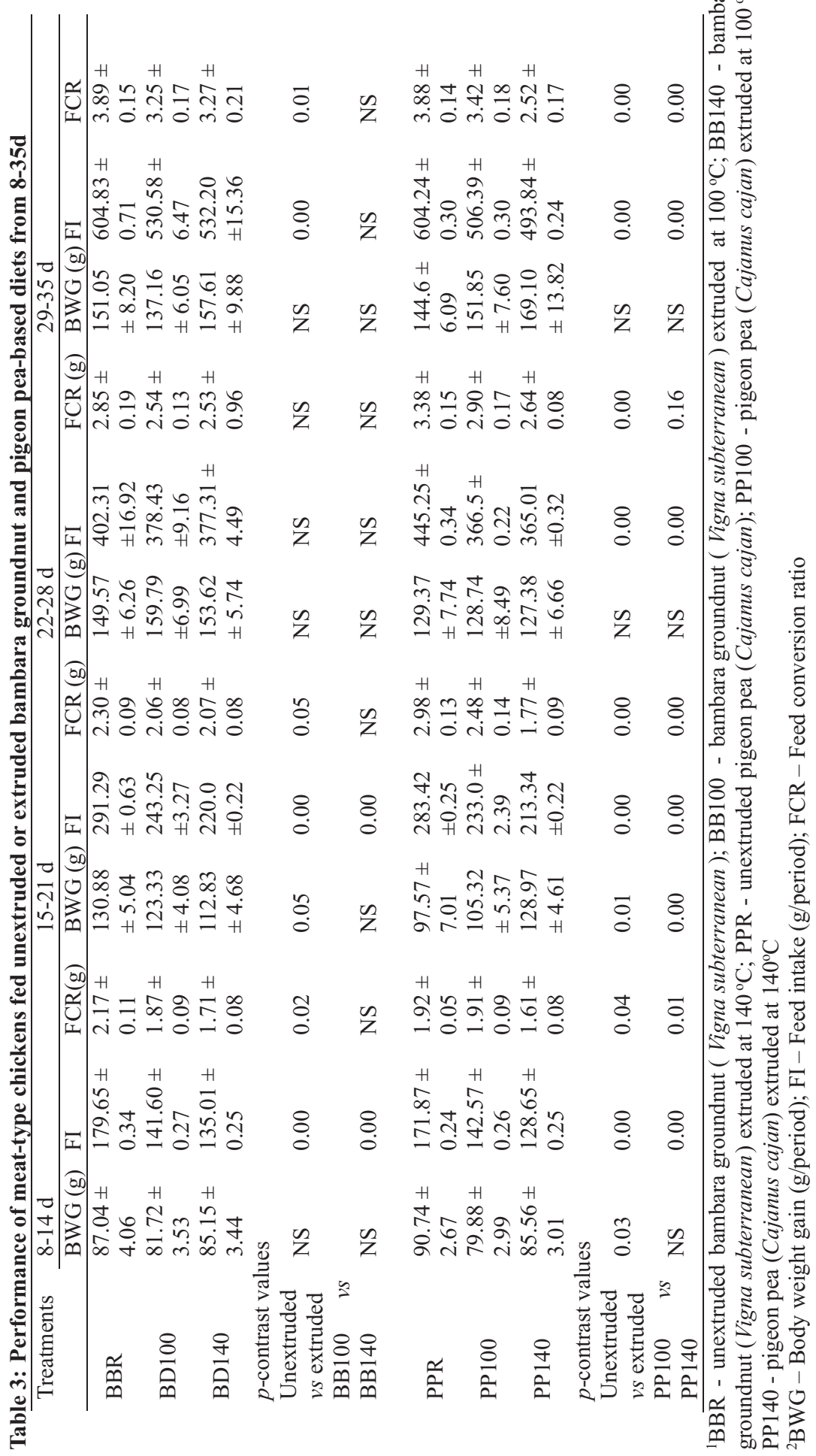




\section{Adeleye, Oduntan, Agunbiade and Farayibi}

chickens when fed at $350-356 \mathrm{~g} / \mathrm{kg}$ of diet in the grower (11-28d) and finisher (29-42d) phases (Diaz et al., 2006). The effects of extrusion and temperature on the relative weight and length of intestinal sections and relative organ weights of meat-type chickens fed the experimental diets are summarized in Figures 2 and 3. No changes in relative weight and length of intestinal segments; duodenum, jejunum, and ileum, as well as organs; proventriculus, gizzard, pancreas and liver, were observed in meattype chickens when unextruded and extruded test diets compared. To the contrary, Arija et al. (2006) reported a decrease in the weight of digestive accessory organs; pancreas and liver, and the jejunum in response to extrusion cooking of kidney beans incorporated in the diet of meat-type chickens at $300 \mathrm{~g} / \mathrm{kg}$ of the total diet. The effects of extrusion and extrusion temperatures on endogenous enzyme activity; pancreatic amylase, trypsin and chymotrypsin activity of meattype chickens fed the experimental diets are reported in Table 4. No effect of extrusion cooking (unextruded $v s$ extruded) or extrusion temperatures was observed on the activity of pancreatic amylase as well as trypsin and chymotrypsin activity in jejunal and ileal digesta of meat-type chickens fed unextruded or extruded bambara groundnut and pigeon pea-based diets. The activity of jejunal and ileal disaccharidases was also unaffected by extrusion cooking (unextruded vs extruded). However, a significant effect of extrusion temperatures was observed on jejunal maltase activity in meat-type chickens on the extruded bambara groundnut diets (BB100 vs BB140) and ileal sucrase in meat-type chickens on the extruded pigeon pea diets (PP100 vs PP140). Compensatory activities of the pancreas of chickens in response to upregulated cholecystokinin production in the presence of protease inhibitors results in upregulation of pancreatic enzyme secretions and consequently pancreatic hypertrophy and hyperplasia (Clarke and Wiseman, 2005; Hill, 2003). However in this study no differences were observed in the activity of pancreatic amylase and proteases in meat-type chickens fed the unextruded vs extruded grain legumes in their diets. 

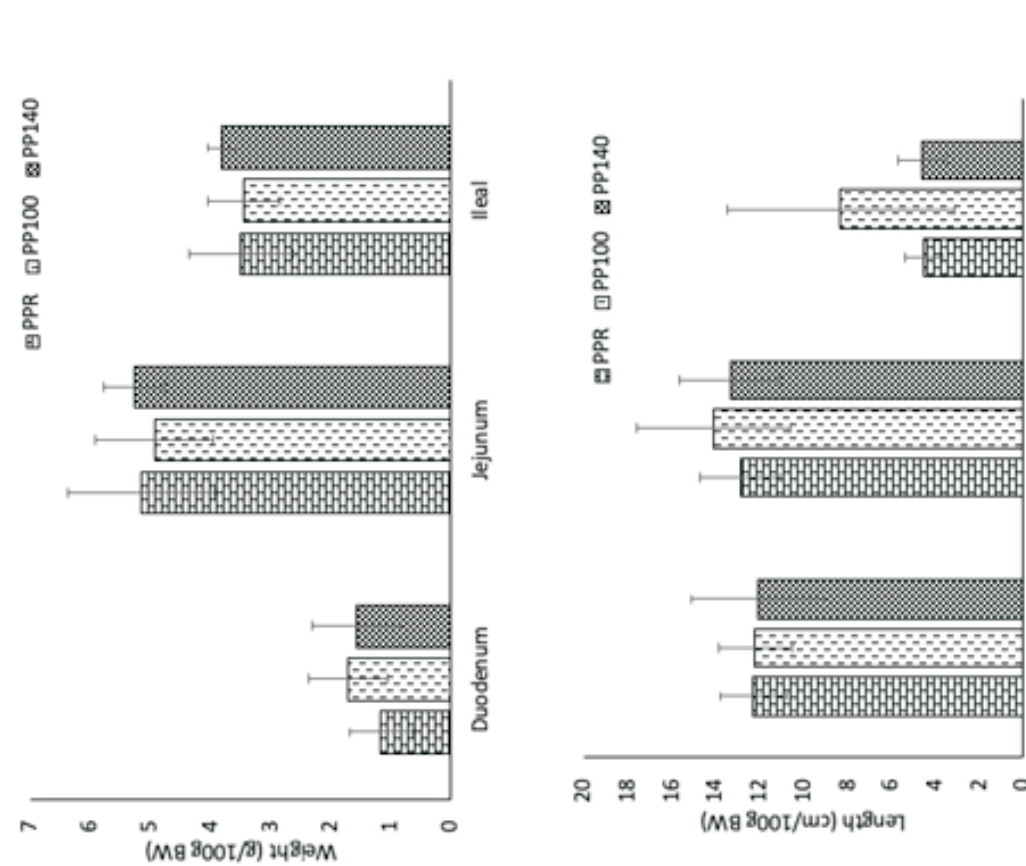

$\infty$
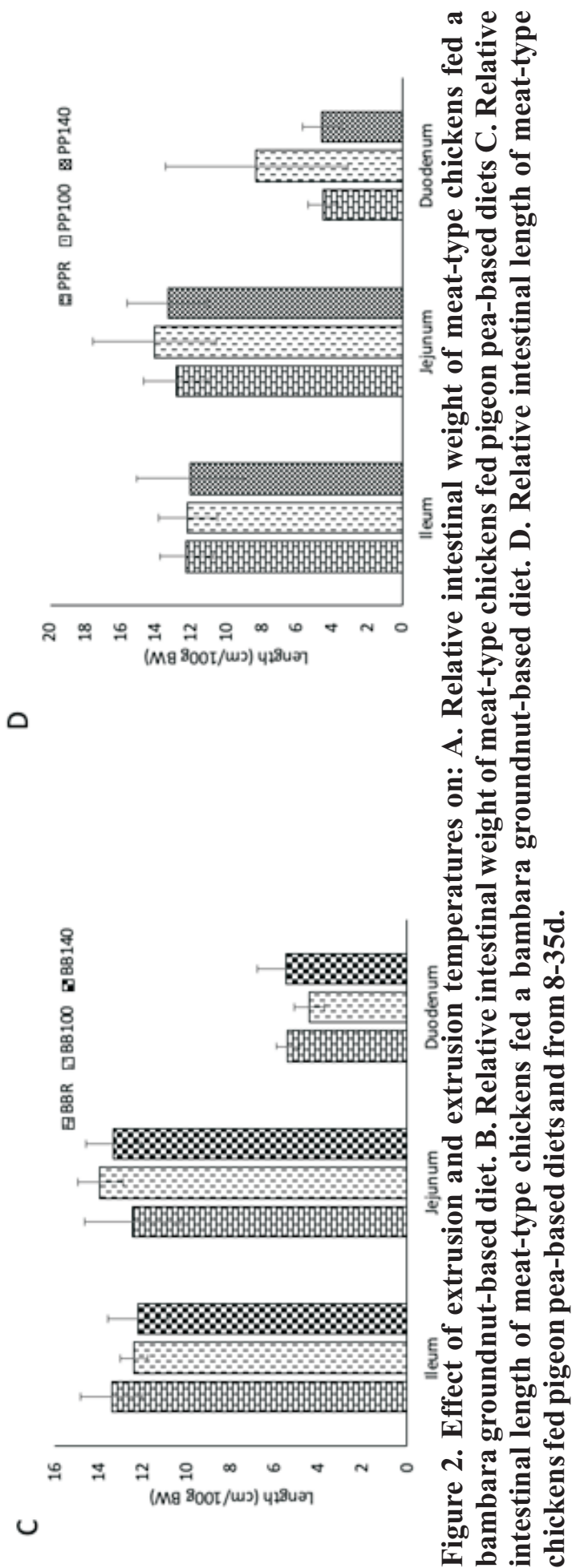
Adeleye, Oduntan, Agunbiade and Farayibi

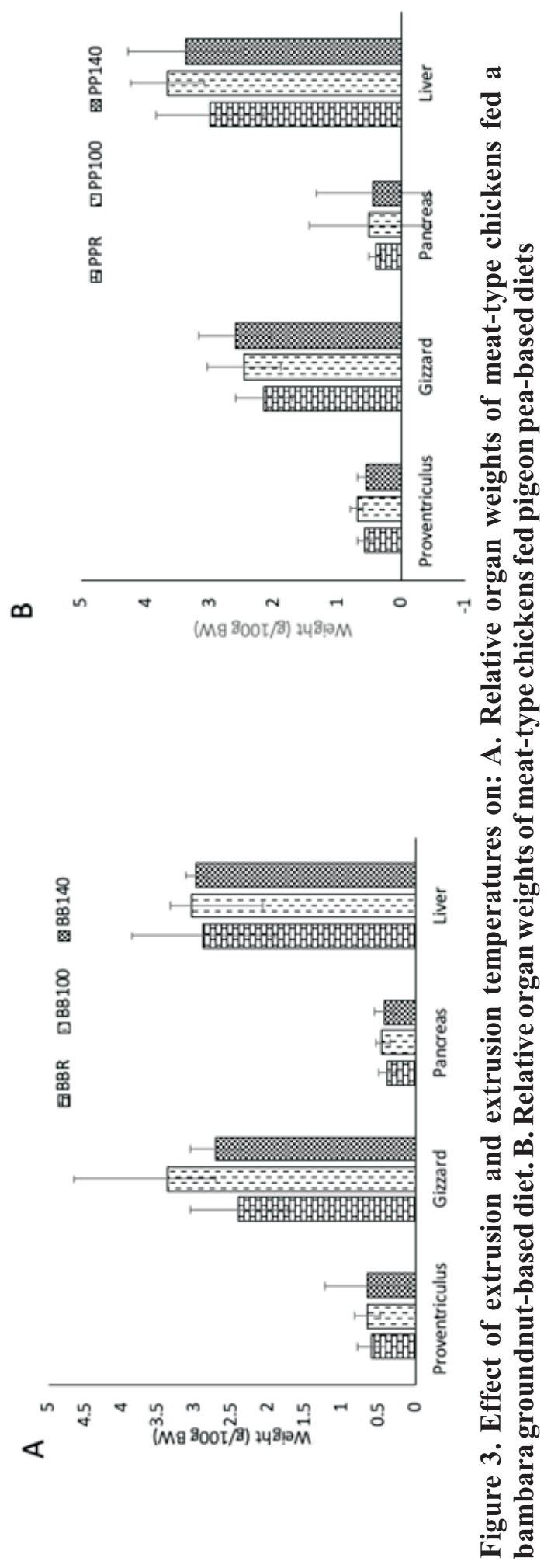


Prospecting extruded grain legumes for meat-type chickens

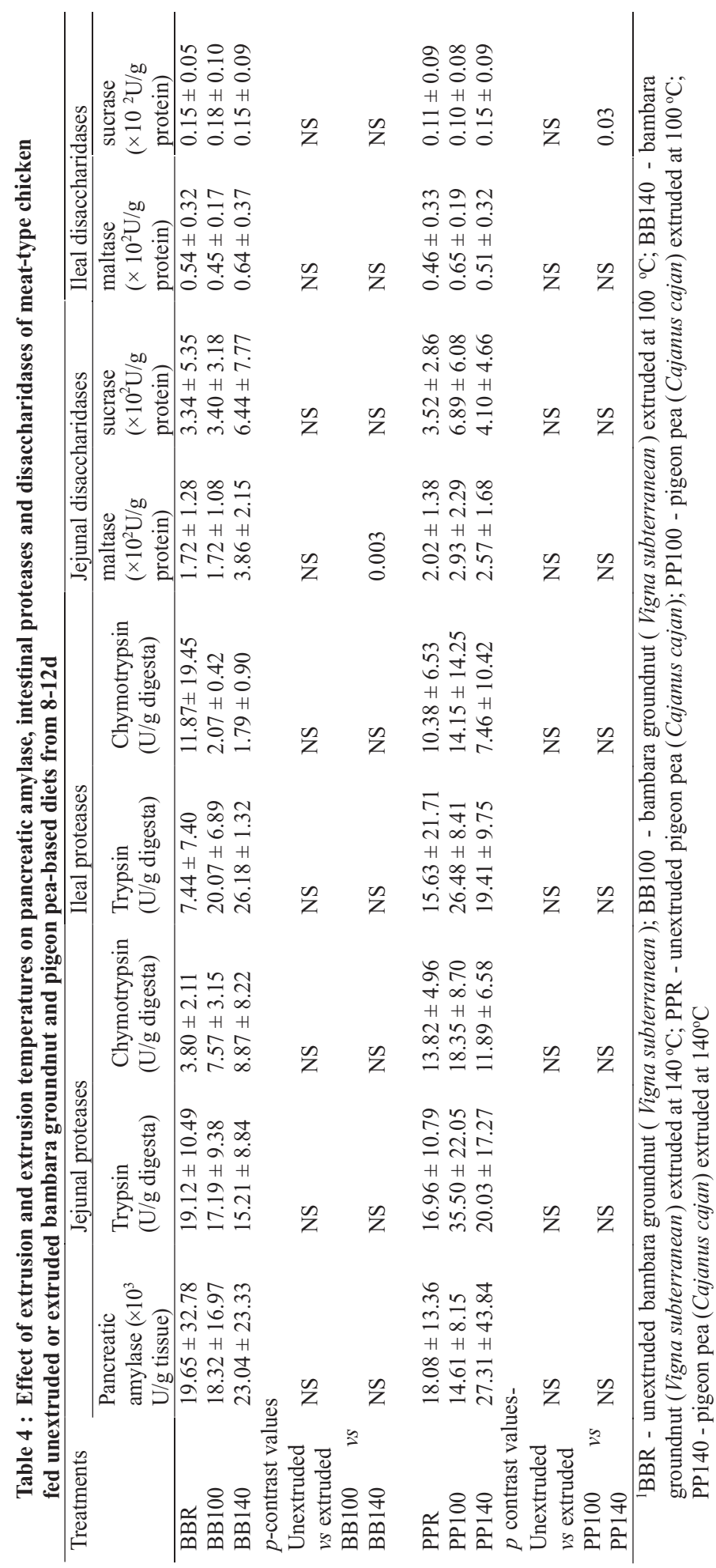




\section{Adeleye, Oduntan, Agunbiade and Farayibi}

The effects of extrusion and extrusion temperatures on residual starch in the jejunal and ileal digesta and excreta of meat-type chickens fed the experimental diets are illustrated in Figure 4. No effect of extrusion cooking or extrusion temperatures was observed on residual starch content of the jejunal and ileal digesta, and excreta of meat-type chickens fed the bambara groundnut based diets. However a significant effect of extrusion temperature was observed on the residual starch content of the ileal digesta and excreta of chickens fed the pigeon pea diets, with significantly higher residual starch recorded in chickens on the PP100 diets compared to the PP140 diets, and significantly lower residual starch recorded in chickens on the PP100 diets compared to the PP140 diets. Extrusion cooking of ingredients containing starch is accompanied by significant starch gelatinization, melting and fragmentation. The disruption of the granular structure of starch achieved during the extrusion cooking process increases substrate availability to enzymes and starch digestibility (Abd ElKhalek and Janassens, 2010). In the current study, the measure of residual starch in the jejunal and ileal digesta, and excreta was used to evaluate the extent of starch digestion in response to extrusion of the grain legumes. In contrast to our findings in this study, inclusion of $140^{\circ} \mathrm{C}$ extrudates of peas at $250 \mathrm{~g} / \mathrm{kg}$ of the diet of meat-type chickens improved apparent ileal digestibility of starch without any improvement in the apparent metabolizable energy of the diets (Nalle et al., 2011). Similar studies investigating faba beans extrudates at $300 \mathrm{~g} / \mathrm{kg}$ of the diet of meat-type chickens also improved apparent ileal digestibility of starch as well as nitrogen-corrected apparent metabolizable energy of the diets (Hejdysz et al., 2019). The absence of an improvement in starch digestibility of extruded grain legumes compared to the unextruded forms as observed in the current study could be attributed to the formation of amylose-lipid complexes or maillard reaction products which are able to impair starch digestibility (Bhatnagar and Hanna, 1994; Pellegrini et al., 2020).

The effects of extrusion and extrusion temperatures on the small intestinal microstructure of meat-type chickens fed the experimental diets are summarised in Table 5. The crypt depth and thickness of the muscularis in the jejunum and ileum of meat-type chickens fed the pigeon pea diets increased significantly with extrusion cooking and under higher extrusion temperatures, while the villus height: crypt depth ratio decreased under similar conditions. While no effect of extrusion cooking (unextruded vs extruded) was observed in the histological structure of the jejunum of meat-type chickens fed the bambara groundnut diets, a decrease in the crypt depth and thickness of the muscularis, and increase in villus height: crypt depth in response to extrusion of bambara groundnut was observed in the ileum of meat-type chickens. Extrusion at a higher temperature also significantly decreased thickness of the muscularis of the jejunum and increased villus height and villus height: crypt depth in the ileum of meat-type chickens fed the bambara diet. The villus height, crypt depth and thickness of the muscularis are often used as indices of intestinal health. While an increase in villus height interprets as an increase in surface area which supports a higher capacity for absorption of digested nutrients, an increase in crypt depth is suggestive of an increase in tissue turnover which is required for villi renewal (Ma and Guo, 2008).Previous studies have shown seemingly inconsistent reports on the effect of extrusion cooking on the small intestinal microstructure. While inclusion of extruded coloured flower-pea at 150$300 \mathrm{~g} / \mathrm{kg}$ of meat-type chicken diets had no 


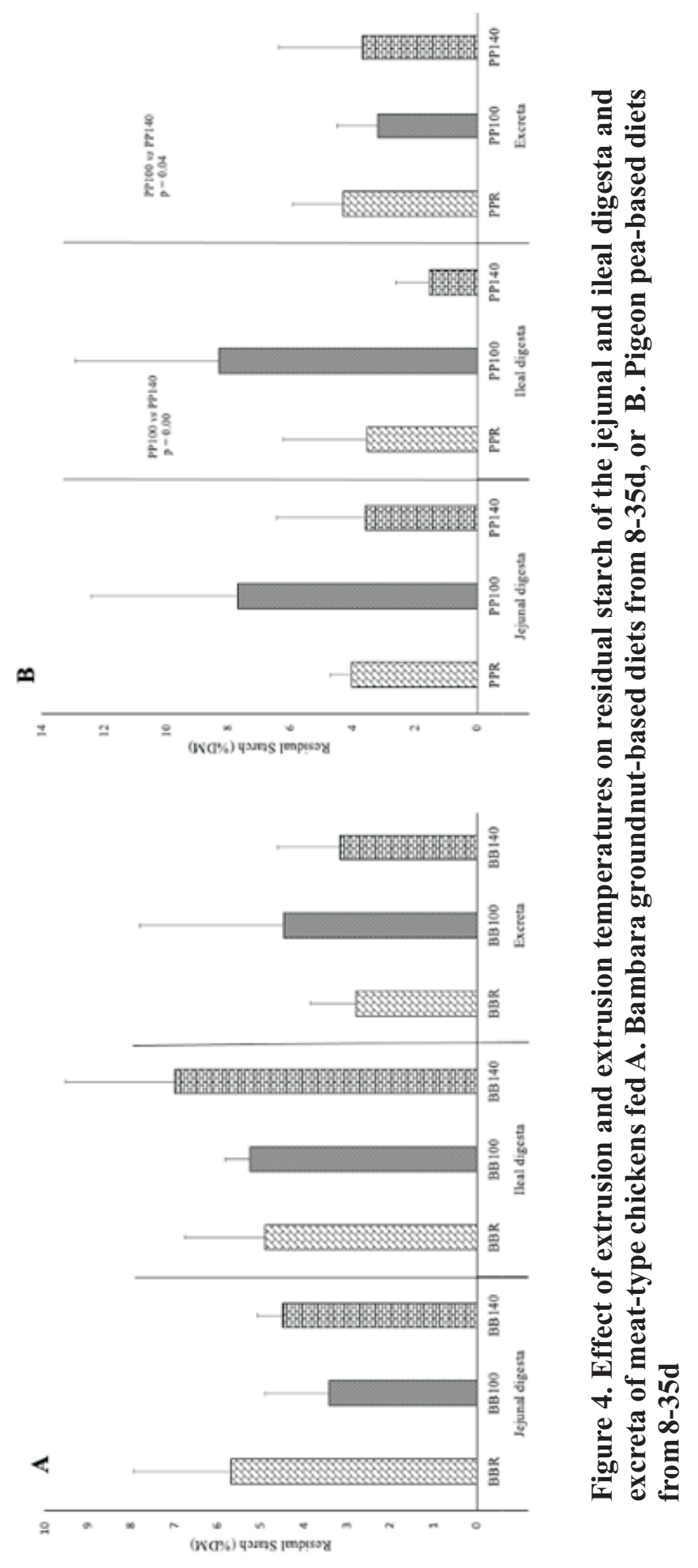


Adeleye, Oduntan, Agunbiade and Farayibi

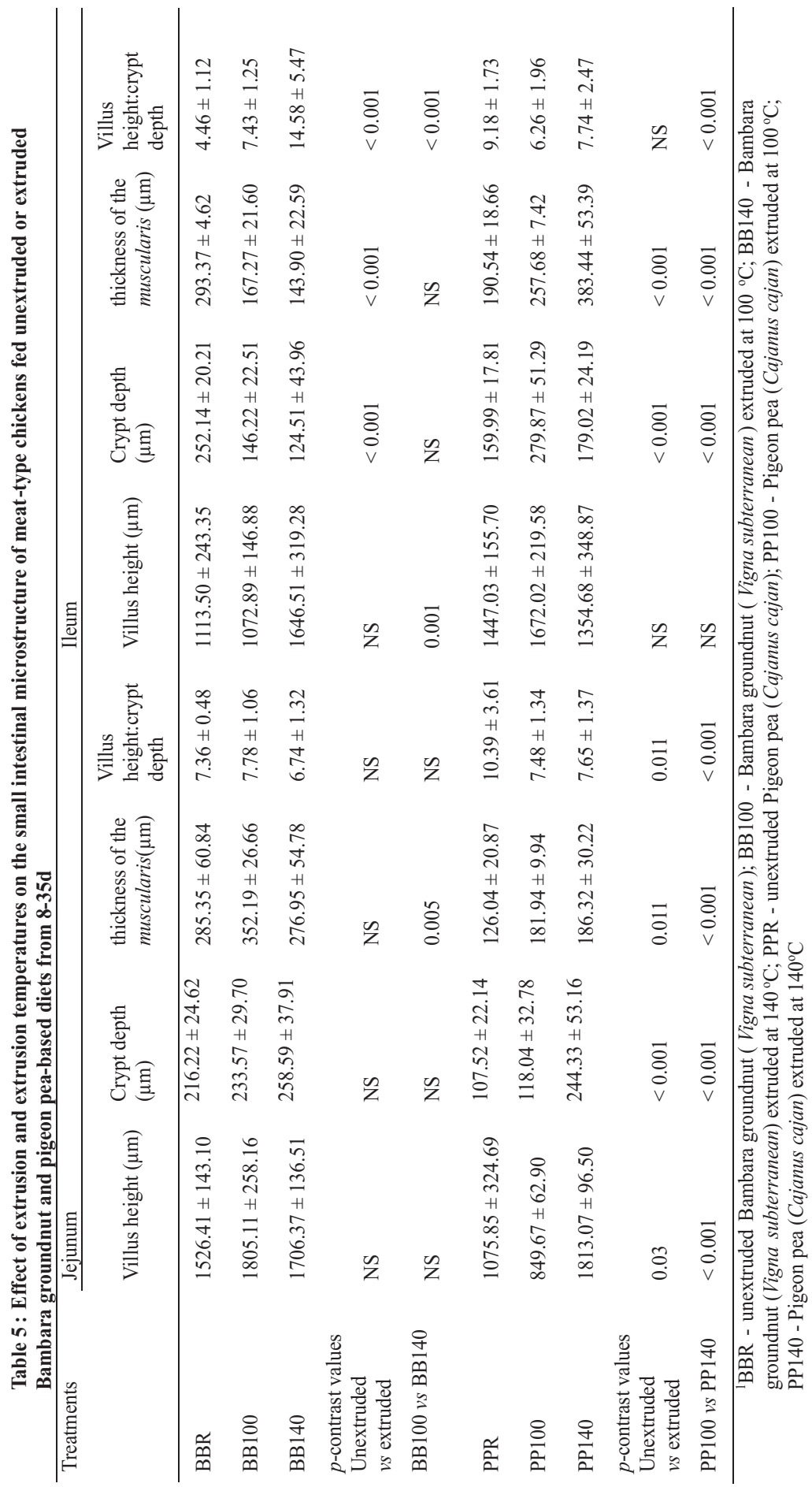


effect on jejunal microstructure, inclusion of extruded full-fat soyabean at $40-120 \mathrm{~g} / \mathrm{kg}$ diet significantly decreases villus height and crypt depth (Foltyn et al., 2013).

\section{Conclusion}

The extrusion of bambara groundnut (Vigna subterranean) and pigeon pea (Cajanus cajan) at either $100^{\circ} \mathrm{C}$ or $140^{\circ} \mathrm{C}$ had varied effects in meat-type chickens. Extrusion cooking of the grain legumes at $100^{\circ} \mathrm{C}$ or $140^{\circ} \mathrm{C}$ decreased feed intake throughout the study without negatively impacting on body weight gain at the end of the $35 \mathrm{~d}$ period, whilst improving feed conversion. Extrusion cooking and extrusion temperatures also had a null effect on development of the gastrointestinal tract; gizzard and small intestine, digestive accessory organs; pancreas and liver, as well as enzyme secretory functions of the pancreas and starch utilization. However the small intestinal microstructure was influenced by extrusion cooking and extrusion temperature, especially in meattype chickens fed the extruded pigeon pea diet.

\section{References}

Abd El-Khalek, E. and Janssens, G. P. J. 2010. Effect of extrusion processing on starch gelatinisation and performance in poultry, World's Poultry Science Journal 66(1): 53-63.

Abdulla, J. M., Rose, S. P., Mackenzie, A. M. and Pirgozliev, V. R. 2017. Feeding value of field beans (Vicia faba L. var. minor) with and without enzyme containing tannase, pectinase and xylanase activities for broilers, Archives of Animal Nutrition 71(2): 150-164. $\mathrm{R}$ e $\mathrm{t} \mathrm{r} \mathrm{i}$ e $\mathrm{ved}$ f $\mathrm{r}$ o m https://www.tandfonline.com/doi/f ull/10.1080/1745039X.2017.1283 823
Adeleye, O. O., Awodiran, S. T., Ajayi, A. O. and Ogunmoyela, T. F. 2020a. Influence of extrusion cooking on physicochemical properties and starch digestion kinetics of Sphenostylis stenocarpa, Cajanus cajan, and Vigna subterranean grains, Plos One 15(12): e0242697. $\mathrm{R}$ e $\mathrm{t}$ r i e v e d f r o m http://dx.doi.org/10.1371/journal.p one.0242697

Adeleye, O. O., Awodiran, S. T., Ajayi, A. O. and Ogunmoyela, T. F. 2020b. Effect of high-temperature, shorttime cooking conditions on in vitro protein digestibility, enzyme inhibitor activity and amino acid pro fi le of selected legume grains, Heliyon 6(October): e05419. $\mathrm{R}$ e t r i e v e d f r o m https://doi.org/10.1016/j.heliyon.2 020.e05419

Alonso, R., Aguirre, A. and Marzo, F. 2000a. Effects of extrusion and traditional processing methods on antinutrients and in vitro digestibility of protein and starch in faba and kidney beans, Food Chemistry 68(2): 159-165.

Alonso, R., Aguirre, A. and Marzo, F. 2000b. Effects of extrusion and traditional processing methods on antinutrients and in vitro digestibility of protein and starch in faba and kidney beans, Food Chemistry 68(2): 159-165.

Alonso, R., Orúe, E. and Marzo, F. 1998. Effects of extrusion and conventional processing methods on protein and antinutritional factor contents in pea seeds, Food Chemistry 63(4): 505-512.

Abd El-Khalek, E. and Janssens, G. P. J. 2010. Effect of extrusion processing on starch gelatinisation and performance in poultry, World's Poultry Science Journal 
66(1): 53-63.

Abdulla, J. M., Rose, S. P., Mackenzie, A. M. and Pirgozliev, V. R. 2017. Feeding value of field beans (Vicia faba L. var. minor) with and without enzyme containing tannase, pectinase and xylanase activities for broilers, Archives of Animal Nutrition 71(2): 150-164. $\mathrm{R}$ e $\mathrm{t} \mathrm{r}$ i e $\mathrm{ved}$ f r o m https://www.tandfonline.com/doi/f ull/10.1080/1745039X.2017.1283 823

Adeleye, O. O., Awodiran, S. T., Ajayi, A. O. and Ogunmoyela, T. F. 2020a. Influence of extrusion cooking on physicochemical properties and starch digestion kinetics of Sphenostylis stenocarpa, Cajanus cajan, and Vigna subterranean grains, Plos One 15(12): e0242697. $\mathrm{R}$ e $\mathrm{t} \mathrm{r}$ i e $\mathrm{v}$ e d f r o m http://dx.doi.org/10.1371/journal.p one.0242697

Adeleye, O. O., Awodiran, S. T., Ajayi, A. O. and Ogunmoyela, T. F. 2020b. Effect of high-temperature, shorttime cooking conditions on in vitro protein digestibility, enzyme inhibitor activity and amino acid pro fi le of selected legume grains, Heliyon 6(October): e05419. $\mathrm{R}$ e t r i e $\mathrm{ved}$ f r o m https://doi.org/10.1016/j.heliyon.2 020.e05419

Alonso, R., Aguirre, A. and Marzo, F. 2000a. Effects of extrusion and traditional processing methods on antinutrients and in vitro digestibility of protein and starch in faba and kidney beans, Food Chemistry 68(2): 159-165.

Alonso, R., Aguirre, A. and Marzo, F. 2000b. Effects of extrusion and traditional processing methods on antinutrients and in vitro digestibility of protein and starch in faba and kidney beans, Food Chemistry 68(2): 159-165.

Alonso, R., Orúe, E. and Marzo, F. 1998. Effects of extrusion and conventional processing methods on protein and antinutritional factor contents in pea seeds, Food Chemistry 63(4): 505-512.

Ani, A. O. and Okeke, G. C. 2011. The performance of broiler birds fed varying levels of roasted Pigeonpea (Cajanus cajan) seed meal, Pakistan Journal of Nutrition 10(11): 1036-1040.

AOAC. 1995. Official methods of analysis . Association of official analytical chemists. Washington DC, USA., 16th Ed., Washington DC.

Arija, I., Centeno, C., Viveros, A., Brenes, A., Marzo, F., Illera, J. C. and Silvan, G.2006. Nutritional evaluation of raw and extruded kidney bean (Phaseolus vulgaris L. var. Pinto) in chicken diets, Poultry Science 85(4): 635-644.

Bello, K., Doma, U. and Ousseini, M. 2005. Effect of two processing methods of Bambaranut (Voandzeia Subterranean) on the performance of broiler chickens, Global Journal of Pure and Applied Sciences 11(3): 335-337.

Bhatnagar, S. and Hanna, M. A. 1994. Amylose-Lipid Complex Formation During Single-Screw Extrusion of Various Corn Starches'. Cereal Chemistry 71(6): 582-587.

Brenes, A., Viveros, A., Centeno, C., Arija, I. and Marzo, F. 2008. Nutritional value of raw and extruded chickpeas (Cicer arietinum L.) for growing chickens, Spanish Journal of Agricultural Research 6(4): 537-545.

Campos-Vega, R., Loarca-Piña, G. and 
Oomah, B. D. 2010. Minor components of pulses and their potential impact on human health, Food Research International 43(2): 461-482. Retrieved from http://dx.doi.org/10.1016/j.foodres .2009.09.004

Clarke, E. and Wiseman, J. 2005. Effects of variability in trypsin inhibitor content of soya bean meals on true and apparent ileal digestibility of amino acids and pancreas size in broiler chicks, Animal Feed Science and Technology 121(1-2): 125-138.

Dahlqvist, A. 1984. Assay of intestinal disaccharidases., Scand. J. Clin. Lab. Invest. 44: 169-172.

Diaz, D., Morlacchini, M., Masoero, F., Moschini, M., Fusconi, G. and Piva, G. 2006. Pea seeds (Pisum sativum), faba beans (Vicia faba var. minor) and lupin seeds (Lupinus albus var. multitalia) as protein sources in broiler diets: Effect of extrusion on growth performance, Italian Journal of Animal Science 51(1): 43-53.

Foltyn, M., Rada, V., Lichovníková, M., Šafař́k, I., Lohniský, A. and Hampel, D. 2013. Effect of extruded full-fat soybeans on performance, amino acids digestibility, trypsin activity, and intestinal morphology in broilers, Czech Journal of Animal Science 58(10): 470-478.

Food and Agriculture Organization of the United Nations. 1995. Sorghum and millets in human nutrition, Rome. Retrieved from http://www.fao.org/docrep/T0818 E/T0818E00.htm

Hejdysz, M., Kaczmarek, S. A., Kubiś, M., Adamski, M., Perz, K. and Rutkowski, A.2019. The effect of faba bean extrusion on the growth performance, nutrient utilization, metabolizable energy, excretion of sialic acids and meat quality of broiler chickens, Animal 13(8): 1583-1590.

Hejdysz, M., Kaczmarek, S. A., Kubiś, M., Jamroz, D., KasprowiczPotocka, M., Zaworska, A. and Rutkowski, A. 2018. Effect of increasing levels of raw and extruded narrow-leafed lupinseeds in broiler diet on performance parameters, nutrient digestibility and AME N value of diet, Journal of Animal and Feed Sciences 27(1): 55-64.

Heuzé, V., Tran, G. and Lebas, F. 2016. Bambara groundnut (Vigna subterranea) seeds., Feedipedia, a Programme by INRA, CIRAD, AFZ and FAO. Retrieved from https://feedipedia.org/node/530 Last updated on July 29, 2016, 10:07

Hill, G. 2003. Plant Antinutritonal Factors /Characteristics, In B. Caballero (Ed.), Encyclopedia of Food Sciences and Nutrition, 2nd ed., Academic Press, pp. 4578-4587. $\mathrm{R}$ e t r i e v e d f r o m https://doi.org/10.1016/B0-12227055-X/01318-3.

J A S P 20200 . J A S P (Version 0.12.2)[Computer software].

Józefiak, D., Ptak, A., Kaczmarek, S., Ma, P., Sassek, M. and Slominski, B. A. 2010. Multi-carbohydrase and phytase supplementation improves growth performance and liver insulin receptor sensitivity in broiler chickens fed diets containing full-fat rapeseed. Poultry Science 89 :1939-1946.

Kim, B. G. and Lindemann, M.D. 2007. A spreadsheet method for experimental animal allotment, Journal of Animal Science 
85(Suppl. 2): 112.

Ma, Y. L. and Guo, T. 2008. Intestinal morphology, brush border and digesta enzyme activities of broilers fed on a diet containing $\mathrm{Cu} 2^{+}$-loaded montmorillonite. British Poultry Science49(1): 65-73.

Mavromichalis, I. 2015. The maillard reaction's impact on animal nutrition. Feed Strategy - News and Analysis for the global animal feed industry. 8 May. Retreived 7 D e c e mber, 2021 , from https://www.feedstrategy.com/fee d-mill-management/the-maillardreactions-impact-on-animalnutrition/

Nalle, C. L., Ravindran, G. and Ravindran, V. 2011. Extrusion of Peas (Pisum sativum L.): Effects on the Apparent Metabolisable Energy and Ileal Nutrient Digestibility of Broilers, American Journal of Animal and Veterinary Sciences 6(1): 25-30.

NRC1994. Nutrient requirements of poultry. 9th rev. ed., National Acadademy of Sciences, National Academy Press, Washington, DC.

Oshodi, A. A., Olaofe, O. and Hall, G. M. 1993. Amino acid, fatty acid and mineral composition of pigeon pea (cujunus cujan), International Journal of Food Sciences and Nutrition 43: 187-191.

Pellegrini, N., Vittadini, E. and Fogliano, V. 2020. Designing food structure to slow down digestion in starchrich products, Current Opinion in Food Science 32: 50-57. Retrieved $\mathrm{f}$ r $\quad \mathrm{o} \quad \mathrm{m}$ https://doi.org/10.1016/j.cofs.2020 .01 .010
Raji, M. O., Adeleye, O. O., Mosobalaje, M. A., Ogunjimi, J. T. and Tewe, O. O. 2016. Growth response and serum biochemical parameters of starter broiler chickens fed toasted African yam bean (Sphenostylis stenocarpa) seeds meal with enzyme supplementation, Arch. Zootec 65(250): 139-143.

Rutkowski, A., Kaczmarek, S. A., Hejdysz, M. and Jamroz, D. 2016. Effect of extrusion on nutrients digestibility, Metabolizable Energy and Nutritional value of yellow lupine seeds for broiler chickens, Annals of Animal Science 16(4): 1059-1072.

Singh, S., Gamlath, S. and Wakeling, L. 2007. Nutritional aspects of food extrusion: A review, International Journal of Food Science and Technology 42(8): 916-929.

Son, J. and Ravindran, V. 2012. Influence of extrusion of white lupins on the apparent metabolizble energy and ileal nutrient digestibility for broilers, International Journal of Poultry Science 11(9): 565-569.

Vasanthan, T. 2001. Enzymatic Quantitation of Total Starch in Plant Products, Current Protocols in Food Analytical Chemistry 00(1): E2.2.1-E2.2.9. Retrieved from http://doi.wiley.com/10.1002/0471 142913.fae0202s00

Received: $9^{\text {th }}$ August, 2021 Accepted: $15^{\text {th }}$ December, 2021 